\title{
Trace mineral status of the African Buffalo (Syncerus caffer) in the Kruger National Park
}

\author{
M.E.A. Erasmus, E.C. Webb ${ }^{\#}$ and J.B.J. Van Ryssen \\ Dept of Animal and Wildlife Sciences, University of Pretoria, Pretoria, 0002 \\ \#e-mail: ecwebb@postino.up.ac.za
}

\section{Introduction}

The chemical composition of body tissues generally reflects the dietary status of domestic and wild animals to varying degrees, depending on the tissue and the element. Chemical estimations on tissues can therefore be used to assist in the detection and definition of a range of mineral inadequacies in mammals. The liver is particularly useful because it serves as a storage organ for certain minerals. The mineral content of the liver thus indicates the nutritional mineral levels, and may be an indication of soil mineral levels and/or the ability of the forage plants to assimilate minerals from the soil. The aim of this paper is to report on the mineral status of the African buffalo in the Kruger National Park (KNP).

\section{Materials and Methods}

Liver samples were taken from 666 buffalo. The liver was transported in buffered formalin and kept in cold storage until analysis. From the available liver samples, two hundred and four were randomly selected for analysis. Each liver sample was cut into pieces and dried at a temperature of $100^{\circ} \mathrm{C}$ for a period of at least $24 \mathrm{~h}$ and the dry livers were milled. Copper, manganese and cobalt concentrations were measured using atomic absorption spectrophotometry. Selenium concentration in the liver samples was measured on an atomic absorption spectrometer with a hydride generator attachment. The mineral concentrations obtained were used to compile a map showing the different levels in different areas of the KNP. Data was analysed by multifactor analysis of variance (SAS, 1992). The KNP was divided into different regions, A-D being the northern and central region of the park above the Olifants River, E the south central region below the Olifants River and F the southern region.

\section{Results and Discussion}

The effects of region, sex and age on the mineral status of African buffalo are presented Tables 1 to 4 . Significant differences $(\mathrm{P}<0.05)$ were observed in the concentrations of copper and selenium in liver samples of buffalo sampled in different regions (Table 1). Highest concentrations of selenium and copper were observed in the northern and central part of KNP above the Olifants River. Significantly lower concentrations of both selenium and copper were found in samples from buffalo culled in the southern part of KNP. The concentration of manganese also differed $(\mathrm{P}<0.05)$ between buffalo sampled from regions $\mathrm{E}$ and $\mathrm{F}$ (Table 2$)$.

Table 1 The effect of region in the Kruger National Park on the average $\mathrm{Cu}$ and Se concentration in the liver of the African Buffalo

\begin{tabular}{lll}
\hline Regions & $\begin{array}{l}\mathrm{Se}(\mathrm{SE}) \\
(\mathrm{mg} / \mathrm{kg} \mathrm{DM})\end{array}$ & $\begin{array}{l}\mathrm{Cu}(\mathrm{SE}) \\
(\mathrm{mg} / \mathrm{kg} \mathrm{DM})\end{array}$ \\
\hline $\mathrm{A}-\mathrm{D}$ & $1.183(0.03934)^{\mathrm{a}}$ & $138.13(10.63)^{\mathrm{a}}$ \\
$\mathrm{E}$ & $0.630(0.03693)^{\mathrm{b}}$ & $131.54(9.98)^{\mathrm{a}}$ \\
$\mathrm{F}$ & $0.414(0.03401)^{\mathrm{c}}$ & $85.26(9.14)^{\mathrm{b}}$ \\
\hline within the same column with different superscripts differ significantly $(\mathrm{P} \leq 0.05)$
\end{tabular}

Table 2 The effect of region in the Kruger National Park on the average mineral concentration in the liver of the African Buffalo (Regions E and F only).

\begin{tabular}{lllll}
\hline Regions & $\begin{array}{l}\mathrm{Se}(\mathrm{SE}) \\
(\mathrm{mg} / \mathrm{kg} \mathrm{DM})\end{array}$ & $\begin{array}{l}\mathrm{Cu}(\mathrm{SE}) \\
(\mathrm{mg} / \mathrm{kg} \mathrm{DM})\end{array}$ & $\begin{array}{l}\text { Co (SE) } \\
(\mathrm{mg} / \mathrm{kg} \mathrm{DM})\end{array}$ & $\begin{array}{l}\text { Mn (SE) } \\
(\mathrm{mg} / \mathrm{kg} \text { DM) }\end{array}$ \\
\hline $\mathrm{E}$ & $0.641(0.02682)^{\mathrm{a}}$ & $135.14(13.66)^{\mathrm{a}}$ & $3.91(0.09)$ & $6.75(0.25)^{\mathrm{a}}$ \\
$\mathrm{F}$ & $0.423(0.02554)^{\mathrm{b}}$ & $64.54(16.97)^{\mathrm{b}}$ & $3.82(0.08)$ & $7.52(0.24)^{\mathrm{b}}$ \\
\hline
\end{tabular}

${ }^{\mathrm{a}, \mathrm{b}}$ Means within the same column with different superscripts differ significantly $(\mathrm{P} \leq 0.05)$ 


\section{Short paper and poster abstracts: $38^{\text {th }}$ Congress of the South African Society of Animal Science}

The selenium concentration of liver samples from buffalo bulls was significantly higher $(\mathrm{P}<0.05)$ compared to buffalo cows (Table 3), particularly in the northern part of KNP. This suggests a greater storage capacity in buffalo bulls or higher selenium requirements for physiological processes such as pregnancy and lactation in cows. Minor differences in selenium concentrations were observed between age groups, with highest concentrations in buffalo of between 1 and 11 years of age (Table 4).

Table 3 The effects of sex on the average mineral concentration in the livers of African Buffalo within regions A D of the Kruger National Park

\begin{tabular}{lllll}
\hline Sex & $\begin{array}{l}\text { Se }(\mathrm{SE}) \\
(\mathrm{mg} / \mathrm{kg} \mathrm{DM})\end{array}$ & $\begin{array}{l}\mathrm{Cu}(\mathrm{SE}) \\
(\mathrm{mg} / \mathrm{kg} \mathrm{DM})\end{array}$ & $\begin{array}{l}\text { Co }(\mathrm{SE}) \\
(\mathrm{mg} / \mathrm{kg} \mathrm{DM})\end{array}$ & $\begin{array}{l}\text { Mn (SE) } \\
(\mathrm{mg} / \mathrm{kg} \mathrm{DM})\end{array}$ \\
\hline $\mathrm{F}$ & $0.830(0.14378)^{\mathrm{a}}$ & $180.10(21.93)$ & $3.96(0.16)$ & $7.34(0.53)$ \\
$\mathrm{M}$ & $1.147(0.12867)^{\mathrm{b}}$ & $165.34(19.62)$ & $3.99(0.15)$ & $7.48(0.48)$ \\
\hline \multicolumn{4}{c}{${ }^{\mathrm{a}, \mathrm{b}}$ Means within the same column with different superscripts differ significantly $(\mathrm{p} \leq 0.05)$}
\end{tabular}

Table 4 The effect of age on the average mineral concentration in livers of the African Buffalo.

\begin{tabular}{lllll}
\hline Age & $\begin{array}{l}\text { Se }(\mathrm{SE}) \\
(\mathrm{mg} / \mathrm{kg} \mathrm{DM})\end{array}$ & $\begin{array}{l}\mathrm{Cu}(\mathrm{SE}) \\
(\mathrm{mg} / \mathrm{kg} \mathrm{DM})\end{array}$ & $\begin{array}{l}\text { Co }(\mathrm{SE}) \\
(\mathrm{mg} / \mathrm{kg} \mathrm{DM})\end{array}$ & $\begin{array}{l}\text { Mn (SE) } \\
(\mathrm{mg} / \mathrm{kg} \mathrm{DM})\end{array}$ \\
\hline 0 & $0.353(0.03969)^{\mathrm{a}}$ & $90.78(14.58)$ & $3.83(0.13)$ & $8.12(0.40)$ \\
$1-6$ & $0.490(0.02052)^{\mathrm{b}}$ & $82.92(7.54)$ & $3.97(0.07)$ & $8.03(0.21)$ \\
$7-11$ & $0.494(0.03047)^{\mathrm{b}}$ & $69.73(11.20)$ & $4.04(0.10)$ & $7.43(0.31)$ \\
$12+$ & $0.384(0.14245)$ & $52.35(7.25)$ & $3.51(0.46)$ & $7.02(1.45)$ \\
\hline
\end{tabular}

${ }^{\mathrm{a}, \mathrm{b}}$ Means within the same column with different superscripts differ significantly $(\mathrm{P} \leq 0.05)$

\section{Conclusion}

It appears that most areas of the KNP have adequate mineral levels when the trace mineral tissue levels of cattle (Puls, 1994) are used as reference. The hepatic concentrations of selenium and copper indicate that there are significant differences in the different regions of the KNP, with marginal deficiencies in the southern regions. A significant difference in selenium status between different sexes was also observed in the KNP, particularly in the northern region.

\section{References}

Puls, R., 1994. Mineral Levels in Animal Health. $2^{\text {nd }}$ edition. Diagnostic Data.

SAS, 1992. SAS users guide. SASInstitute Inc., Cary, NC. 